\begin{tabular}{|c|c|c|}
\hline & Int.J.Curr.Microbiol.App.Sci (2018) 7(3): 366-372 & \multirow{2}{*}{ 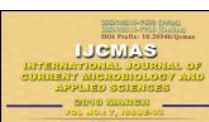 } \\
\hline & \multirow{3}{*}{$\begin{array}{l}\text { International Journal of Current Microbiology and Applied Sciences } \\
\text { ISSN: 2319-7706 Volume } 7 \text { Number } \mathbf{0 3} \text { (2018) } \\
\text { Journal homepage: http://www.ijcmas.com }\end{array}$} & \\
\hline & & \\
\hline $\begin{array}{l}\text { EXCELLENT } \\
\text { PUBL ISHERS }\end{array}$ & & \\
\hline
\end{tabular}

\title{
Studies on Boron Fractions with Different Physico-Chemical Properties in more than Ten Year Old Arecanut Plantations
}

\author{
H.C. Nagaveni* and C.T. Subbharayappa \\ Department of SS \& AC, COH, Mudigere - 577132, India \\ *Corresponding author
}

\section{A B S T R A C T}

\begin{tabular}{|c|}
\hline Keywords \\
\hline $\begin{array}{l}\text { Boron, Organic } \\
\text { carbon, pH, Different } \\
\text { fractions, Path } \\
\text { analysis, Correlation }\end{array}$ \\
\hline Article Info \\
\hline $\begin{array}{l}\text { Accepted: } \\
\text { 04 February } 2018 \\
\text { Available Online: } \\
10 \text { March } 2018\end{array}$ \\
\hline
\end{tabular}

A soil survey was conducted in three talluks (Davangere, Channagiri and Honnali) of more than ten year old arecanut plantations of Karnataka to assess status of available boron, its different fractions and its relationship with other properties of soil. Soil analysis for physical and chemical properties revealed that these soils belongs to sandy loam to sandy clay loam texture with neutral to alkaline $\mathrm{pH}$, having low $\mathrm{EC}$ with low to medium organic matter $(0.09$ to $1.56 \%)$ content and cation exchange capacity ranged from 7.55 to 21.38 $\mathrm{Cmol}(\mathrm{p}+) \mathrm{kg}^{-1}$. The Available boron content was sufficient and varies from 0.12 to 1.02 $\mathrm{mg} \mathrm{kg}^{-1}$. Zinc fractions like Rs-B, Sp-B, Ox-B Org-B, Res-B Total were varied from 0.23 $0.89,0.23-1.56,2.12-10.23,1.13-8.56,46.33-212.65$ and $56.97-233.54 \mathrm{mg} \mathrm{g}^{-1}$. Available B recorded significant, positive correlation with Sp-B, Ox-B, negatively with, Rs-B, Org-B and Total-B but non-significant, negative correlation with Res-B. The oxide bound boron fraction was relatively higher than the readily soluble and specifically adsorbed forms, major portion of boron in soils existed as residual or occluded forms which accounted for 92.9 to 98.9 per cent of total boron.

\section{Introduction}

Arecanut is an extensively cultivated tropical palm the nuts of which form a popular mastricatory across all classes, age groups, and gender and social groups uniformly in India. It belongs to a family Palmae and originated in India. The emergence of new product such as panmasala and gutkha further made a fill up the demand pattern of arecanut. This has resulted in a remunerative price for farmers leading to rapid expansion in area not only in traditional growing regions, but also in non-traditional Maidan (Chitradurga, Davangere, and some parts of Shimoga) as well as in irrigated tracts (coastal plains of Dakshina Kannada, Udupi, Shimoga and hilly terrains of Chikamangalore district) of Karnataka. The area under arecanut is around 4 lakh hectares with a production of around 4.78 lakh tons in India. Karnataka and Kerala together account for 70 per cent of area and production of arecanut. In Karnataka, around 2.15 lakh hectares are under arecanut cultivation (Ramappa and manjunatha, 2013).

Arecanut can be grown in a variety of soils such as laterities, red loamy etc. Being a perennial, propagated through seeds and selfpollinated crop, it started yielding at the age of 
more than 5 years and consistent yield is obtained after ten years of planting. With the introduction of high yielding varieties and the concomitant usage of high analysis fertilizers over a period of time, has boosted the crop yields. However, it has caused depletion of native available nutrients and more so the micronutrients like boron, zinc and others. Such micronutrient deficiency in recent years has become the major limiting factor in crop production.

Boron is one of the important micronutrient required for balanced growth of plants. Boron concentration between plant deficiency and toxicity is narrow. In India about $2 \%$ boron deficiency was initially reported by Katyal and Vlek (1985). But now a day it is increased to $18.3 \%$ (Kusum et al., 2017). With respect to arecanut it has many nutrient disorders which will reduces the yield in that nut splitting, nut, flower dropping are main and these are the result of boron deficiency. So this investigation was carried out to investigate different forms in boron, their relation with soil physico-chemical properties and their contribution for pool of available boron was carried out in selected arecanut gardens at Davangere district of Southern Transitional Zone of Karnataka viz., Channagiri, Honnali and Davangere talluks.

The fractions of boron fractions includes readily soluble boron, specifically adsorbed boron oxide bound boron, organically bound boron and Residual fraction, their association plays a vital role in determining its availability to plants. The dynamic equilibrium among the different chemical pools of boron indicates the replenishment of readily available boron by other pools of soil boron, as and when former fraction gets depleted. Adequate quantity of soil boron the changes in the equilibrium between the various chemical pools of soil boron depends upon the Physico-chemical properties and inherent ability of soil to supply these nutrients, in addition to distributional and environmental factors.

\section{Materials and Methods}

The representative, thirty six soil samples at 0$20 \mathrm{~cm}$ depth was collected from different taluks of Davangere district. Collected soil samples were air dried under shade, powdered by using wooden pestle and mortar, passed through $2 \mathrm{~mm}$ sieve and stored in a polyethylene bags. For organic carbon determination, $2 \mathrm{~mm}$ sieved samples were further subjected for grinding and passed through $0.2 \mathrm{~mm}$ sieve.

The samples were analyzed for texture, $\mathrm{pH}$, EC, CEC, organic carbon (Jackson, 1958) and available B (Berger and Troug, 1939) and its fractions like, readily soluble boron, specifically adsorbed boron, oxide bound boron, organically bound boron, residual fraction and total boron content using standard procedure.

\section{Results and Discussion}

The particles that make up soil are categorized into three groups by size - sand, silt, and clay. Sand particles are the largest and clay particles the smallest. Most soils are a combination of the three. The relative percentages of sand, silt, and clay are what give soil its texture. The texture of the analyzed samples of Channagiri, Honnali and Davangere taluks belongs to sandy loam to sandy clay loam, with higher sand $(78.26 \%)$ which might be due to granite parent material from which the soil was derived. and clay $(29.46 \%)$ at Davangere (Table 1). Similar results were given by Prashantha (2012) and Jayaprakash et al., (2012).

Soil samples from all the three taluks were neutral to alkaline in nature, alkalinity may probably due to continuous irrigation with 
alkaline water or may be less weathered parent material (Chirwa and Yerokun, 2012), higher $\mathrm{pH}$ was recorded in Davangere talluk (8.60). The electrical conductivity was low in all the soils in arecanut plantations and it is normal for plant function and production same as observed by Krishnamurthy and Govindarajan (1977) and Jyothi et al., (2009).

The organic carbon content is medium to high in all soil samples, this might be due to continuous cultivation, different management practices adopted by the farmers because these plantations are started yielding at higher quantity. Higher organic carbon content (1.56 $\%$ ) was recorded in Davangere talluk. Cation exchange capacity was high in most of the soils, this may be due to higher organic carbon content noticed in present study and also supported by other workers like Vadiraj and Rudrappa (1990). Higher value was (21.38 cmol $\left.(\mathrm{p}+) \mathrm{kg}^{-1}\right)$ recorded in Channagiri talluk. Higher values of $0.75 \mathrm{mg} \mathrm{kg}^{-1}$ of $\mathrm{B}$ were recorded in Davangere taluk.

The soil samples were analyzed for different boron fractions viz., readily soluble (Rs-B), specifically adsorbed ( $\mathrm{Sp}-\mathrm{B})$, oxide bound (Ox-B), organically bound (org-B), residual fraction (Res-B) and total boron content.

Fractionation of boron in soils has provided an insight into its binding form and availability in soils (Shuman, 1986). Total content of boron in soils varied from $56.97-179.23 \mathrm{mg} \mathrm{kg}{ }^{-1}$, which is well within the reported range (7-630 $\mathrm{mg} / \mathrm{kg}$ ) of total boron for Indian soils (Kanwar and Randhawa, 1974). It is well within the range as reported by Anita et al., (2011) in southern transition Zone (245 $\mathrm{mg} \mathrm{kg}^{-1}$ ).

The readily soluble boron represented in small proportion of total boron, in all taluks of arecanut plantations of southern transition zone (Anita et al., 2011). Residual Boron content was found to be low and fallowed by
Sp-B, Org-B, Ox-B, Res-B and total-B, similar trend was noticed in all the taluks of Davangere district.

The oxide bound boron fraction was relatively higher than the readily soluble and specifically adsorbed forms, indicating that oxides and oxy hydroxides play an important role in boron fixation and the formation of inner-sphere surface complexes. The major portion of boron in soils existed as residual or occluded forms which accounted for 92.9 to 98.9 per cent of total boron. This might be due to most of the boron presumably found within the crystalline structures of mineral soils. Hou et al., (1994) also reported that residual fraction of boron constituted as much as 99 per cent of the total boron in some soils of Ontario.

The results indicated that the readily soluble boron fraction had a significant and positive relationship with $\mathrm{pH}(\mathrm{r}=0.814)$ and $\mathrm{OC}$ (0.850). Similar results were reported by Kusuma et al., (2017) this pool of boron includes dissolved plus boron adsorbed nonspecifically on edges of clays and other variable charge surfaces (Hou et al., 1994). The positive effects of soil $\mathrm{pH}$ on readily soluble boron is described to the fact that increasing $\mathrm{pH}$ increases the negative surface charges of clays and other variable charge surfaces (Hingston, 1964). Specifically adsorbed boron correlated significantly and positively with $\mathrm{pH}(\mathrm{r}=932)$, this might be due to specifically adsorbed on to clay surfaces or associated with organic matter in soil. A nonsignificant and positive correlation was observed with clay, this is due to fraction probably originates from the strongly binding sites of both organic and inorganic constituents and this constituents contributed exclusively towards this boron fraction but negatively correlated with organic carbon content of soil. Oxide bound correlated positively with clay and non-significant with $\mathrm{pH}$ and OC content of soil (Table 2-4). 
Table.1 Physical properties

\begin{tabular}{|c|c|c|c|c|c|c|}
\hline Sl. No & Taluks & & Sand (\%) & Silt (\%) & Clay (\%) & TG \\
\hline \multirow[t]{2}{*}{1.} & \multirow[t]{2}{*}{ Channagiri } & Range & $58.98-68.28$ & $6.52-16.64$ & $16.21-28.65$ & \multirow{6}{*}{$\begin{array}{l}\text { sandy loam } \\
\text { to sandy } \\
\text { clay loam }\end{array}$} \\
\hline & & Mean & 64.48 & 10.28 & 24.63 & \\
\hline \multirow[t]{2}{*}{2.} & \multirow[t]{2}{*}{ Honnali } & Range & $58.9-68.26$ & $6.8-16.25$ & $20.1-28.28$ & \\
\hline & & Mean & 63.88 & 12.65 & 23.27 & \\
\hline \multirow[t]{2}{*}{3.} & \multirow[t]{2}{*}{ Davangere } & Range & $58.1-78.26$ & $3.98-15.38$ & $16.21-29.46$ & \\
\hline & & Mean & 65.06 & 9.65 & 24.67 & \\
\hline
\end{tabular}

Table.2 Chemical properties

\begin{tabular}{|c|c|c|c|c|c|c|}
\hline Sl. No. & Taluks & & pH & EC & OC & CEC \\
\hline \multirow{2}{*}{ 1. } & Channagiri & Range & $7.3-8.6$ & $0.06-0.26$ & $0.27-1.56$ & $7.55-19.14$ \\
\cline { 3 - 7 } & \multirow{2}{*}{ Honnali } & Mean & 8.07 & 0.15 & 0.76 & 14.93 \\
\hline \multirow{2}{*}{ 2. } & Range & $7.9-8.54$ & $0.09-0.25$ & $0.3-0.99$ & $10.92-20.66$ \\
\cline { 3 - 7 } & \multirow{2}{*}{ Davangere } & Mean & 8.25 & 0.14 & 0.58 & 15.24 \\
\hline \multirow{2}{*}{ 3. } & Range & $7.41-8.66$ & $0.12-0.24$ & $0.09-1.17$ & $9.75-21.38$ \\
\cline { 2 - 7 } & & Mean & 8.17 & 0.17 & 0.78 & 16.04 \\
\hline
\end{tabular}

Table.3 Different boron fractions

\begin{tabular}{|c|c|c|c|c|c|c|c|c|c|}
\hline $\begin{array}{l}\text { SI. } \\
\text { No }\end{array}$ & Taluks & & $\begin{array}{c}\text { Avil. B } \\
\text { (ppm) }\end{array}$ & $\begin{array}{c}\text { Rs-B } \\
(\mathrm{ppm})\end{array}$ & $\begin{array}{c}\text { Sp-B } \\
(\mathrm{ppm})\end{array}$ & $\begin{array}{c}\text { Ox-B } \\
\text { (ppm) }\end{array}$ & $\begin{array}{l}\text { Org-B } \\
\text { (ppm) }\end{array}$ & $\begin{array}{r}\text { Res-B } \\
(\text { ppm) }\end{array}$ & $\begin{array}{l}\text { Total } \\
\text { (ppm) }\end{array}$ \\
\hline \multirow[t]{2}{*}{1.} & \multirow{2}{*}{$\begin{array}{l}\text { Channag } \\
\text { iri }\end{array}$} & Range & $0.17-1.02$ & $\begin{array}{l}0.25- \\
0.89\end{array}$ & $0.23-1.56$ & $4.39-8.90$ & $\begin{array}{l}3.98- \\
6.41\end{array}$ & $\begin{array}{l}46.33- \\
123.63\end{array}$ & $56.97-140.85$ \\
\hline & & Mean & 0.47 & 0.51 & 0.80 & 6.71 & 5.08 & 77.76 & 90.86 \\
\hline \multirow[t]{2}{*}{2.} & \multirow[t]{2}{*}{ Honnali } & Range & $0.15-0.65$ & $\begin{array}{l}0.23- \\
0.86\end{array}$ & $0.52-1.32$ & $2.12-10.23$ & $\begin{array}{l}1.13- \\
8.56\end{array}$ & $\begin{array}{l}60.12- \\
212.65\end{array}$ & $66.34-233.54$ \\
\hline & & Mean & 0.38 & 0.53 & 1.14 & 5.06 & 3.15 & 83.75 & 93.64 \\
\hline \multirow[t]{2}{*}{3.} & \multirow{2}{*}{$\begin{array}{l}\text { Davange } \\
\text { re }\end{array}$} & Range & $0.12-0.75$ & $\begin{array}{l}0.35- \\
0.85\end{array}$ & $\begin{array}{c}0.42- \\
1.56\end{array}$ & $4.1-9.87$ & $\begin{array}{l}2.84- \\
6.41\end{array}$ & $\begin{array}{l}60.88- \\
159.25\end{array}$ & $\begin{array}{c}69.78- \\
179.23\end{array}$ \\
\hline & & Mean & 0.24 & 0.56 & 1.00 & 6.21 & 4.95 & 84.97 & 97.70 \\
\hline
\end{tabular}

Table.4 Correlation coefficient (r) between different fractions of boron with soil properties

\begin{tabular}{|l|l|l|l|}
\hline Boron fractions & pH & clay & OC \\
\hline Rs-B & $0.814 * *$ & -0.267 & $0.850 * *$ \\
\hline Sp-B & $0.932 * *$ & $-0.952 * *$ & -0.027 \\
\hline Ox-B & $-0.764 * *$ & $1.000 * *$ & -0.301 \\
\hline Org-B & $-0.591 * *$ & $0.967 * *$ & $0.516 * *$ \\
\hline Res-B & $0.979 * *$ & $-0.631 * *$ & $0.567 * *$ \\
\hline Total & $0.779 * *$ & -0.209 & $0.879 * *$ \\
\hline *Significant at 5\% ** Significant at 1\% & &
\end{tabular}


Table.5 Correlation coefficient (r) between available boron with its fractions and among the fractions in above ten years old arecanut plantations

\begin{tabular}{|c|c|c|c|c|c|c|c|}
\hline & B & Rs-B & Sp-B & Ox-B & Org-B & Res-B & total $(\mathrm{mg} / \mathrm{kg})$ \\
\hline B & 1 & & & & & & \\
\hline Rs-B & -0.416 & 1 & & & & & \\
\hline Sp-B & 0.531 & $0.550 *$ & 1 & & & & \\
\hline Ox-B & $0.778^{*}$ & -0.248 & $-0.945^{* *}$ & 1 & & & \\
\hline Org-B & $-0.904 * *$ & -0.013 & $-0.843^{* *}$ & $0.972 * *$ & 1 & & \\
\hline Res-B & -0.016 & $0.916 * *$ & $0.839 * *$ & -0.615 & -0.413 & 1 & \\
\hline total(mg/kg) & -0.469 & $0.998 * *$ & $0.499 *$ & -0.190 & 0.046 & $0.891^{* *}$ & 1 \\
\hline
\end{tabular}

$*$ Significant at $5 \% * *$ Significant at $1 \%$

Table.6 Path analysis

\begin{tabular}{|l|l|}
\hline Boron fractions & \multicolumn{2}{|c|}{ Content } \\
\hline Rs-B & -0.949 \\
\hline Sp-B & -0.978 \\
\hline Ox-B & 7.350 \\
\hline Org-B & -8.894 \\
\hline Res-B & 0.315 \\
\hline Total B & 2.487 \\
\hline
\end{tabular}

Fig.1 Different fractions of B on available B

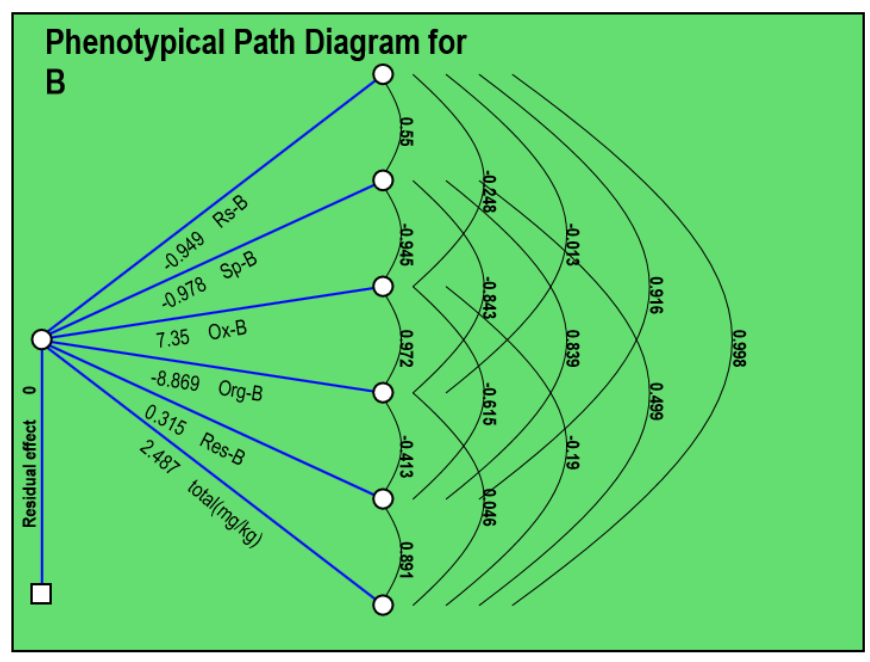

Organically bound boron was correlated nonsignificant correlated with $\mathrm{pH}$ but positively correlated with organic carbon and clay content of soil. Residual boron is positively and significantly correlated with $\mathrm{pH}$ and clay.
The available boron content positively correlated with oxide bound boron $(\mathrm{r}=$ 0.778), specifically adsorbed boron is positively correlated with readily adsorbed boron $(\mathrm{r}=0.550)$ oxide bound boron was 
positively correlated with available boron $(\mathrm{r}=$ 0.778) and negatively correlated with specially adsorbed boron $(\mathrm{r}=-945)$ (Table 5). This shows a strong relationships between available boron and fractions, such relationships suggest that the extractants used were reasonably selective in the fractions extracted (Fig. 1).

Oxide bound boron was negatively correlated with available boron $(\mathrm{r}=-0.904)$, specially adsorbed boron $(\mathrm{r}=-0.843)$ and positively correlated with oxide bound boron ( $\mathrm{r}=$ 0.972). residual boron was positively and significantly correlated with residual boron ( $\mathrm{r}$ $=0.916)$ and specially adsorbed boron $(\mathrm{r}=$ 0.839). Total boron was positively correlated with readily adsorbed boron $(\mathrm{r}=0.998)$, specially adsorbed boron $(\mathrm{r}=0.499)$ and residual boron (0.891). The oxide bound boron fraction includes tightly bound boron at the mineral surface as well as boron that has isomorphously replaced by $\mathrm{Al}$ or $\mathrm{Fe}$ within the octahedral sheet of the minerals (Hou et al., 1994). Specifically adsorbed boron correlated non-significantly but positively and negatively with other fractions of boron (Table 6).

Organically bound boron significant but positively correlated with residual and total boron in below five year plantations but in other aged plantations it is negatively nonsignificant. A significant and positive correlation was observed between residual boron and total boron, this would suggest that the sequential extraction procedure was also found to be satisfactory in terms of precision.

Among the boron fractions Ox-B had positive direct effect on available B compared to other fractions. It might be due to oxides and oxy hydroxides which play an important role in boron fixation and the formation of innersphere surface complexes. Rs-B, Sp-B, Org-B and Res-B also has direct effect on available
$\mathrm{B}$ but in negligible amount. The soils arecanut plantations of more than ten year old belongs to sandy loam to sandy clay loam texture with neutral to alkaline $\mathrm{pH}$, having low EC with low to medium organic matter (0.09 to 1.56 $\%)$ content and cation exchange capacity ranged from 7.55 to $21.38 \mathrm{Cmol}(\mathrm{p}+) \mathrm{kg}^{-1}$. The Available boron content was sufficient and varies from 0.12 to $1.02 \mathrm{mg} \mathrm{kg}^{-1}$. Zinc fractions like Rs-B, Sp-B, Ox-B Org-B, ResB Total-B were varied from $0.23-0.89,0.23$ $1.56,2.12-10.23,1.13-8.56,46.33-212.65$ and $56.97-233.54 \mathrm{mg} \mathrm{g}^{-1}$. Available B recorded significant, positive correlation with Sp-B, Ox-B, negatively with, Rs-B, Org-B and Total-B but non-significant, negative correlation with Res-B. The oxide bound boron fraction was relatively higher than the readily soluble and specifically adsorbed forms, major portion of boron in soils existed as residual or occluded forms which accounted for 92.9 to 98.9 per cent of total boron.

\section{References}

Anitha, M. S. 2011. Distribution of boron in some identified soils and land use systems of Karnataka. M.Sc., Thesis submitted to UAS, Bangalore.

Berger, K.C. and E. Troug.1939. Boron determination in soils and plants. Ind. Eng. chem. Anal. Ed. 11:540-545.

Hou, J., Evans, L. J. and Spiers, G.A. 1996. Chemical fractionation of soil boron: I. Method development. Can. J. Soil Sci. 76: 485-491.

Jackson, M.L. 1958. Soil Chemical Analysis, prentice Hall Inc., Engle wood Cliffs, New Jersey, p.468.

Jayaprakash, R., Vishwanath Shetty, Y., Punitha, B.C. and Shilpashree, V.M. 2012. Vertical distribution of chemical properties and macro nutrient status in non-traditional areca growing soil 
profiles of Karnataka. Ind. J. Fund. App. Life Sci. 2 (1): 59 -62.

Jyothi, T.V., Vishwanath Shetty, Y. and Dinesh Kumar, M. 2009. Characterization and DTPA- Zn status in traditional arecanut garden soils of south Karnataka. Karnataka J. Agric. Sci., 22(5):1013-1015.

Kanwar, J.S. and Randhawa, N.S. 1974. Micronutrient research in soils and plant in India. A review. Indian Council of Agricultural Research. New Delhi.

Katyal, J.C. and Sharma, B.D. 1991. DTPAextractable and total $\mathrm{Zn}, \mathrm{Cu}, \mathrm{Mn}$ and $\mathrm{Fe}$ in Indian soils and their association with some soil properties. Geoderma, 49: 165-179.

Krishnamurthy, R. and Govindarajan, S.V. 1977. Genesis and Classification of associated red black soil under Rajolibanda diversion irrigation. J. Ind Soc. Soil Sci., 25: 239 - 246

Kusum, Kumara, Gazala Nazir, Ajeet, Singh and Pradeep Kumar. 2017. Studies on Boron Fractions with Different PhysicoChemical Properties of Cultivated soils of Himachal Pradesh, India. Inj.J.Curr.Microbiol.App.Sci., $\quad$ 6(6): 1547-1555.

Meki Chirwa and Olusegun Yerokun, A. 2012. The Distribution of zinc fractions in surface samples of selected agricultural soils of Zambia. J. Ind Soc. Soil Sci., 7: 51-60.

Prashantha, G. M., Chikkaramappa, T. Mahendra Kumar, M. B. Anitha, M. S. Prakash, S. S. and Vijay kumar, C. 2012. Distribution of DTPA-extractable Zinc and their relationship with Physico-chemical properties in rice soils of Davangere district, India. Plant Archieves. 12(1): 371-376.

Ramappa, B.T. and Manjunatha, M. S. 2013. Cost Cultivation of Arecanut NonTraditional Region of Karnataka -An Analysis. International Journal of Pharmaceutical Science Invention, 2(3): $2319-6718$

Vadiraj, B. A. and Rudrappa, N., 1990, Studies on the nutrients status of soil under different plantations. Myforest 26 (2): $157-162$.

\section{How to cite this article:}

Nagaveni, H.C. and Subbharayappa, C.T. 2018. Studies on Boron Fractions with Different Physico-Chemical Properties in more than Ten Year Old Arecanut Plantations. Int.J.Curr.Microbiol.App.Sci. 7(03): 366-372. doi: https://doi.org/10.20546/ijcmas.2018.703.042 